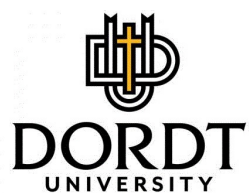

\section{Dordt Digital Collections}

Faculty Work Comprehensive List

$11-2015$

\section{James 3:13-4:10 and the Language of Envy in Proverbs 3:21-35}

Benjamin J. Lappenga

Dordt College, benjamin.lappenga@dordt.edu

Follow this and additional works at: https://digitalcollections.dordt.edu/faculty_work

Part of the Biblical Studies Commons, and the Christianity Commons

\section{Recommended Citation}

Lappenga, B. J. (2015). James 3:13-4:10 and the Language of Envy in Proverbs 3:21-35. Retrieved from https://digitalcollections.dordt.edu/faculty_work/455

This Conference Presentation is brought to you for free and open access by Dordt Digital Collections. It has been accepted for inclusion in Faculty Work Comprehensive List by an authorized administrator of Dordt Digital Collections. For more information, please contact ingrid.mulder@dordt.edu. 


\title{
James 3:13-4:10 and the Language of Envy in Proverbs 3:21-35
}

\begin{abstract}
Although a few interpreters have noted in passing the numerous verbal links between James 3:13-4:10 and LXX Prov 3:21-35, James' passage is regularly read as a polemic against jealousy that is most at home within Hellenistic moral literature. This paper argues that the literary and thematic coherence of James 3:13-4:10 derives not primarily from the Hellenistic topos on envy (so Luke Timothy Johnson) but from metaleptic interplay with Prov 3:21-35. That is, the explicit appeal to "the scripture" in James 4:5 and the citation of Prov 3:34 in James 4:6 indicate that the tropes usually interpreted against the backdrop of Hellenistic moral literature (friendship, violence, etc.) resonate more naturally within the "cave" of Proverbs 3. Like many passages in sapiential literature (e.g., Prov 14:1, 19; 4Q416 2ii11; 4Q418 8,12 ; Wis 1:9-12; Sir 9:1-11), Jas 3:13-4:10 foregrounds the language of "jealousy" to expose the tragedy of bad $\zeta \tilde{n} \diamond \diamond_{\diamond}$. In trying to locate parallels to James' usage in Hellenistic writings, interpreters have failed to appreciate how the movement from $\zeta \tilde{n} \diamond \diamond$ simply resonates with a description found already in Isocrates: an envious person ( $\varphi$ Өóvo $\varsigma$ ) is one whose good emulation ( $\zeta \tilde{n} \diamond \diamond \varsigma$ ) has degenerated into jealous imitation because of unfulfilled desires. More significant than the particular semantic choices, then, is that James' usage mimics the way Prov 3:31 links violent people (Prov 3:27, 29, 31). Using this wisdom motif from Prov 3:21-35 as the interpretive lens for James 3:13-4:10 lends further support to a growing consensus about the notorious interpretive crux in James 4:5; namely, (1) that the formula in 4:5 does not introduce a citation of an unknown text, and (2) that it is the human spirit (rather than God's) that is characterized by "envy" ( $\varphi$ Өóvo૬).
\end{abstract}

\section{Keywords}

James, Proverbs, language, envy, biblical interpretation

Disciplines

Biblical Studies | Christianity

\section{Comments}

Presentation delivered at the annual Society of Biblical Literature conference in Atlanta, Georgia, in November 2015. 


\author{
James 3:13-4:10 and the Language of Envy in Proverbs 3:21-35 \\ Benjamin J. Lappenga, Dordt College \\ Letters of James, Peter, and Jude \\ 11/21/2015 4:00 PM to 6:30 PM Room: 209 (Level 2) - Hilton
}

Theme: Letters of James, Peter, and Jude in the Context of Second Temple Jewish Literature

\begin{abstract}
:
Although a few interpreters have noted in passing the numerous verbal links between Jas 3:13-4:10 and LXX Prov 3:21-35, James' passage is regularly read as a polemic against jealousy that is most at home within Hellenistic moral literature. This paper argues that the literary and thematic coherence of Jas 3:134:10 derives not primarily from the Hellenistic topos on envy (so Luke Timothy Johnson) but from metaleptic interplay with Prov 3:21-35. That is, the explicit appeal to "the scripture" in Jas 4:5 and the citation of Prov 3:34 in Jas 4:6 indicate that the tropes usually interpreted against the backdrop of Hellenistic moral literature (friendship, violence, etc.) resonate more naturally within the "cave" of Proverbs 3. Like many passages in sapiential literature (e.g., Prov 14:1, 19; 4Q416 2ii11; 4Q418 8,12; Wis 1:9-12; Sir 9:1-11), Jas 3:13-4:10 foregrounds the language of "jealousy" to expose the tragedy of

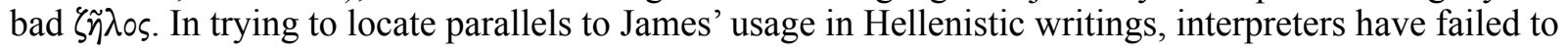

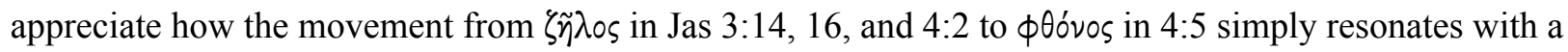

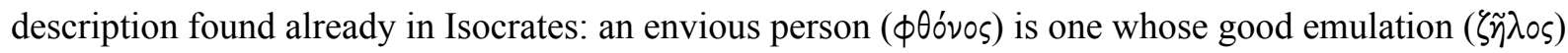
has degenerated into jealous imitation because of unfulfilled desires. More significant than the particular

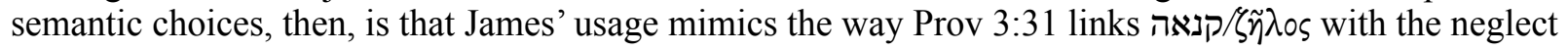
of the needy, distorted friendship, and emulating the ways of evil/violent people (Prov 3:27, 29, 31). Using this wisdom motif from Prov 3:21-35 as the interpretive lens for Jas 3:13-4:10 lends further support to a growing consensus about the notorious interpretive crux in Jas 4:5; namely, (1) that the formula in 4:5 does not introduce a citation of an unknown text, and (2) that it is the human spirit (rather than God's) that is characterized by "envy" ( $\phi$ Oóvos).
\end{abstract}

\title{
1. The Thematic Coherence of James 3:13-4:10 and the Hellenistic Topos on Envy
}

T. Sim. 2.6-7, 13: In the time of my youth I was jealous [ $\left.\dot{\varepsilon}^{\zeta} \zeta \dot{\eta} \lambda \omega \sigma \alpha\right]$ of Joseph...[and] the spirit of jealousy

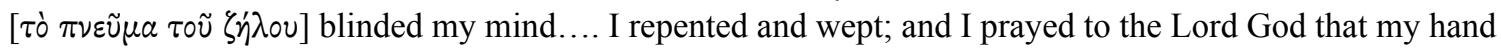
be restored, and that I might refrain from all defilement and envy [фӨóvov] and all foolishness.

\section{Jas 3:13-4:10 as a Reading of Proverbs 3 (LXX) 2.1 James and the Paraenetic Tradition}

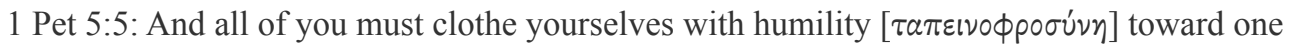
another, since "God opposes the proud, but gives grace to the humble."

Ignatius, Eph. 5.3: Therefore whoever does not meet with [the congregation] is now proud

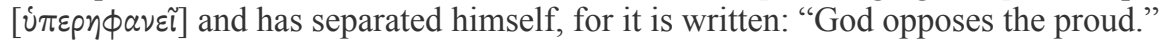

1 Clem. 30.1-2 [L] et us do all the things that pertain to holiness, forsaking...detestable pride

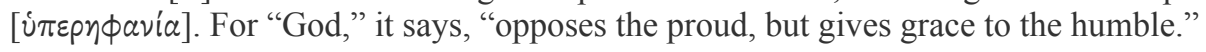

\subsection{Intertextuality}




\subsection{Verbal and Thematic Parallels with Proverbs 3 (LXX)}

\section{James (my translation)}

Jas 2:6 But you have dishonored [ $\left.\tau^{\tau} \tau \mu \alpha \dot{\sigma} \sigma \tau \tau \varepsilon\right]$ the poor.... Jas 2:15 If a brother or sister is naked and is lacking daily food, 16 and one of you should say to them, "Go in peace [Eipท́n ]; be warmed and filled," and yet you do not give them their bodily needs, what is the gain? ...

Jas 3:10 From the same mouth come blessing and cursing

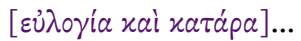

Jas 3:13 Who is wise [бoфós] and understanding among you? Show by your good [ $x a \lambda \tilde{n} s]$ lifestyle that your works

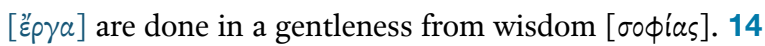
But if you have bitter zeal [ $\zeta \tilde{\eta} \lambda \circ v]$ and strife in your hearts, do not boast and lie with respect to the truth. 15 Such wisdom [ $\left.\sigma \circ \phi^{\prime} \alpha\right]$ does not come down from above, but is earthly, natural, demonic. 16 For where there is zeal $[\zeta \tilde{\eta} \lambda \circ \varsigma]$ and strife, there also is disorder and every evil deed.

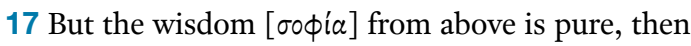

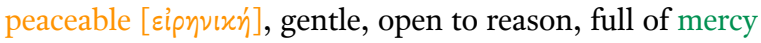

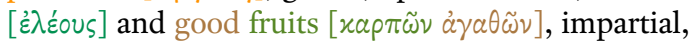
sincere. 18 And the fruit of righteousness [xaptós...

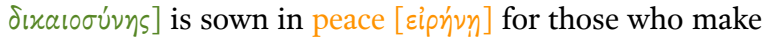

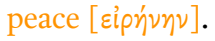

4:1 From where are those conflicts, and from where the quarrels $\left[\mu \alpha^{\prime} \chi \alpha_{l}\right]$ among you? Are they not from here, from come from your cravings [ $\dot{\eta} \delta \circ \nu \tilde{\omega} \nu]$ waging war in your body parts? 2 You desire and do not have, you murder, and you are zealous $[\zeta \eta \lambda \circ \tilde{\tau} \tau \varepsilon]$ and you are not able to obtain, you quarrel $\left[\mu \alpha^{\prime} \chi \varepsilon \sigma \theta \varepsilon\right]$ and fight; you do not have, because you do not ask, 3 you ask and do not receive, because you ask wrongly $[$ xaxĩs], in order to spend freely on your cravings. 4 Adulterers, do you not know that friendship $\left[\phi ı \lambda^{\prime} \alpha\right]$ with the world is enmity [ $\left.\varepsilon^{\prime} \chi \theta p \alpha\right]$ with God? Therefore whoever wishes to be a friend $\left[\phi_{1} \lambda^{i} \mid \alpha\right]$ of the world makes himself an enemy [' ¿ $\chi$ pós] of God. 5 Or do you suppose that the Scripture speaks in vain concerning jealously [ $\pi$ pòs $\phi \theta$ óvov]? The spirit that he has made to dwell in us desires

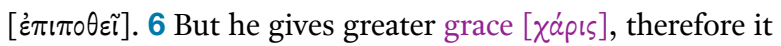
says,

"God resists the proud, but gives grace to the humble."

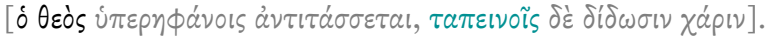

7 Therefore submit yourselves to God, resist the devil, and he will flee from you; 8 draw near to God, and he will draw

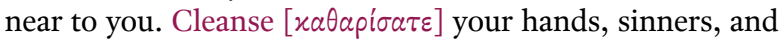
purify $[\dot{\alpha} \gamma \nu i \sigma \alpha \tau \varepsilon]$ your hearts, you double-minded. 9 Lament and mourn and weep. Let your laughter be turned into mourning and joy into gloom. 10 Humble $\left[\tau \alpha \pi \varepsilon เ \nu \omega^{\prime} \theta \eta \tau \varepsilon\right]$ yourselves before the Lord, and he will exalt

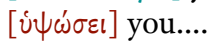

14 You do not know the things of tomorrow [aúpเov].

\section{Proverbs (New English Translation of the Septuagint)}

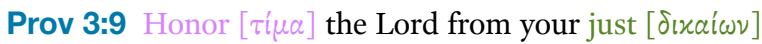
labors, and offer him of your firstfruits of righteousness

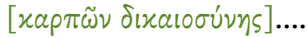

Prov 3:15 And she is more precious $[\tau \tau \mu \iota \omega \tau \varepsilon \dot{\varepsilon} \alpha]$ than precious stones; nothing evil shall resist her; she is wellknown to all those who draw near to her, and nothing

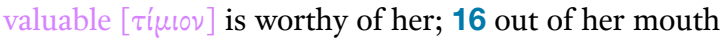
righteousness comes forth, and she carries law and mercy [ $\left.{ }^{\prime} \lambda \varepsilon \circ \nu\right]$ upon her tongue. 17 Her ways are good ways [ódol

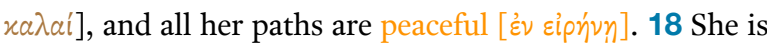
a tree of life to all those who lay claim to her, and she is

steadfast to those who lean upon her, as on the Lord. 19

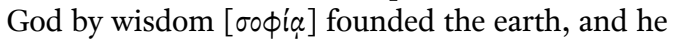
prepared the heavens by prudence. 20 By perception the deeps were broken open, and the clouds poured dew. 21 My son, do not break away, but keep my counsel and insight 22 so that your soul may live and that there may

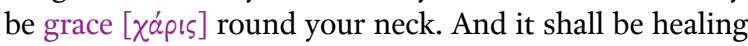
to your flesh and treatment for your bones, 23 that you may walk all your ways confidently in peace [Eiprivn] and that your foot will not stumble. 24 For if you sit down, you will be without fear, and when you lie down, you will sleep pleasantly. 25 And you shall not be afraid of intimidation when it comes, nor of attacks [ópuás; cf. Jas 3:4] of the impious, when they approach. 26 For the Lord will be over all your ways and he will support your foot in order that you may not be unsettled. 27 Do not withhold

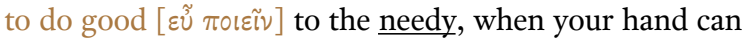

help. 28 Do not say, "Go, come back, and tomorrow [aúp iov] I will give," when you are able to do good [ $\varepsilon \tilde{u}$

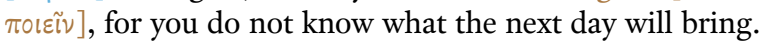
29 Do not plan evil [xaxá] against your friend [ $\phi i \lambda \circ \nu]$ when he lives besides you and trusts in you. 30 Do not quarrel [ $\left.\phi 1 \lambda \varepsilon \chi \theta p \eta \dot{\sigma}\rangle_{\varsigma}\right]$ with anyone without a cause, lest he

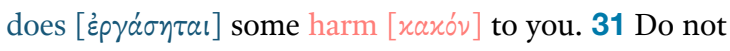
acquire the disgrace of evil [ $x \alpha x \tilde{\omega} \nu]$ men, and do not strive

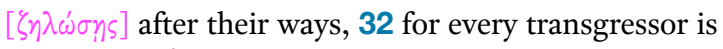

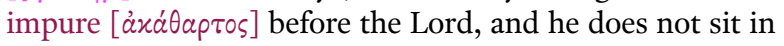

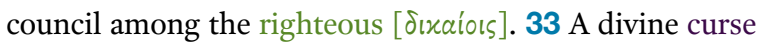

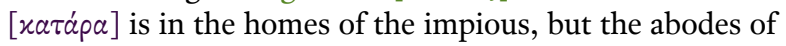

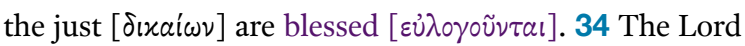
resists the proud, but gives grace to the humble [xúpıs

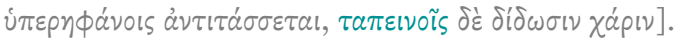

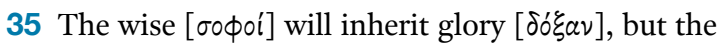
impious have exalted $[\ddot{\psi} \psi \omega \sigma \alpha \nu]$ disgrace $[a \dot{\tau} \tau \mu \dot{i} \alpha \nu] . . .$.

Prov 17:1 Better is a morsel with pleasure in peace [ $[\dot{\gamma} \delta$ v $\tilde{s}$

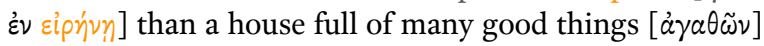
and unjust $\left[\dot{\alpha} \delta^{\prime}(x \omega \nu]\right.$ sacrifices with strife $\left[\mu \dot{a}^{\prime} \chi \gamma^{\prime}\right]$. 


\section{Readings of Proverbs in Jewish Sapiential Literature \\ 3.1. The Wisdom of Solomon, the Sentences of Pseudo-Phocylides, and Sirach}

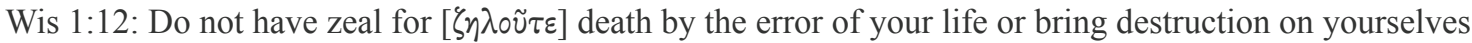
by the deeds of your hands.

Wis 2:24: Through the envy [ $\phi$ tóvos] of the devil death entered the world, and those who belong to his party experience it.

Wis 6:23: Nor indeed will I travel in the company of consumptive envy [ $\phi$ Өóvos], because this can have no fellowship with wisdom.

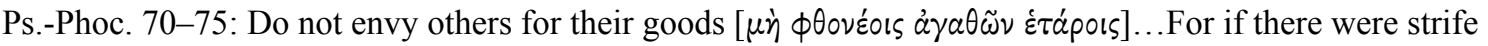
[épls] among the blessed, the city would not stand.

Sir 9:1: Do not be jealous [ $\left.\mu \dot{\eta} \zeta \eta^{\prime} \lambda{ }^{\prime} v\right]$ of the wife of your bosom, nor teach an evil lesson against yourself. Sir 9:11: Do not envy [ $\left.\mu \grave{\eta} \zeta \eta \lambda \omega^{\prime} \sigma \eta \xi\right]$ a sinner's fame, for you do not know what his ruin will be.

\subsection{Sapiential Texts from Qumran and the Language of Zeal (קניאה)}

4Q418 f8:6 [do not] exchange your holy spirit [for any amount of money,]...

4Q418 f8:11 ...[do not let any money be left over] without [...] lest he should say, He has defrauded me and $[\ldots]$

4Q418 f8:12 [... and behold how] powerful is human jealousy [קנאת]. It deceives the heart [...]

4Q424 f3:7 A man of insight will receive under[standing,] a man of knowledge can recognize wisdom [...]

4Q424 f3:8 An honest man will take pleasure in good judgment. A man of truth [...] a strong man will be zealous [יקנא] for [...]

4Q424 f3:9 [and h]e disputes with those who would shift the boundaries. A man of compa[ssion does] justice to the needy [...]

4Q424 f3:10 [...] concern for all those who lack money, the children of the righteous $[\ldots]$

1QS 4:2-5: One enlightens a man's mind, making straight before him the paths of true righteousness and causing his heart to fear the laws of God. And this is a spirit of humility [ענוה], patience, great compassion [רחמים], everlasting goodness [טוֹב], insight, understanding, and mighty wisdom entrusting to each of God's deeds, sustained by his abundant mercy. A קנאת] spirit of knowledge of every plan of action, and of zeal for the laws of righteousness [שפטי צדק], holy in thought, and firm in inclination.

1QS 4:9-10: The operations of the spirit of falsehood result in greed, neglect of righteous deeds, wickedness, lying, pride and haughtiness, cruel deceit and fraud, massive hypocrisy, a want of self-control and abundant foolishness, a zeal [קנאת]for arrogance, abominable deeds fashioned by whorish desire, lechery in its filthy manifestation,

1QS 4:18: Zeal attends every point of decision [וקנאת ריב על כול משפטיהן], for they can never agree. 1QS 4:23: Until now the spirits of truth and perversity have contended within the human heart.

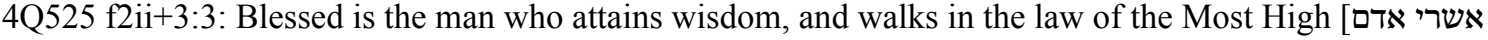

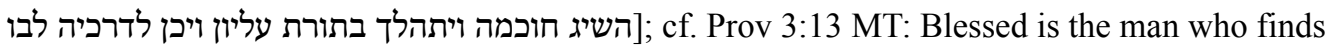

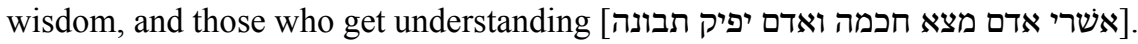

4Q525 f5:13-f7:5: Those who love God walk humbly in it and in [the] wa[ys of...] [...without] answer and having zeal [ומקנאת] without [...] that he might not understand because of an erra[nt] spirit [... that he might not] know because of a perverted spirit [...] with weakness and causes stumbling witho[ut ...] certainty and sends away without...pride and exalts [גאוה ומרימת without [... and ]honor[s without ...] because of the inclination of [...] thoughts [...] because of a troubl[ed] spirit. 


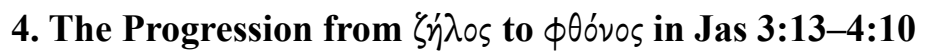

Isocrates, Antid. 244-259: I am of the opinion that... all those who are envious of my success covet the ability to

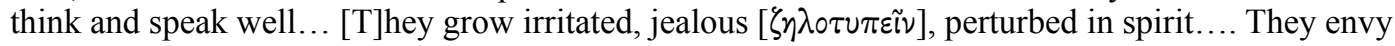

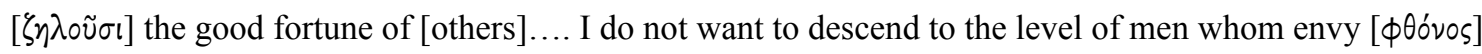
has made blind.

\section{Implications for the Interpretive Crux in Jas 4:5-6}

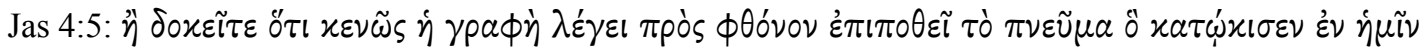

Johnston (2013) following Spitta (1896): Or do you think that the Scripture [Lappenga: Proverbs 3] speaks uselessly in reference to jealousy? The [human] spirit, which [God] caused to dwell in us, inordinately desires.

NRSV: Or do you suppose that it is for nothing that the scripture says, "God yearns jealously for the spirit that he has made to dwell in us"?

NIV 1984: Or do you think Scripture says without reason that the spirit he caused to live in us envies intensely?

NIV 2011: Or do you think Scripture says without reason that he jealously longs for the spirit he has caused to dwell in us?

$C E B$ : Or do you suppose that scripture is meaningless? Doesn't God long for our faithfulness in the life he has given to us?

Vulgate: aut putatis quia inaniter scriptura dicat ad invidiam concupiscit Spiritus qui inhabitat in nobis

Luther Bible: Oder meint ihr, die Schrift sage umsonst: Mit Eifer wacht Gott über den Geist, den er in uns hat wohnen lassen?

\section{Select Bibliography}

Brooke, George J. "Biblical Interpretation in the Wisdom Texts from Qumran." Pages 201-20 in The Wisdom Texts from Qumran and the Development of Sapiential Thought. Edited by Charlotte Hempel, Armin Lange, and Hermann Lichtenberger. Leuven: Uitgeverij Peeters, 2002.

Davids, Peter H. "The Pseudepigrapha in the Catholic Epistles." Pages 228-45 in The Pseudepigrapha and Early Biblical Interpretation. Edited by James H. Charlesworth and Craig A. Evans. Journal for the Study of the Pseudepigrapha Supplement Series 14. Studies in Scripture in Early Judaism and Christianity 2. Sheffield: Sheffield Academic, 1993.

Goff, Matthew J. Discerning Wisdom: The Sapiential Literature of the Dead Sea Scrolls. Supplements to Vetus Testamentum 116. Leiden: Brill, 2007.

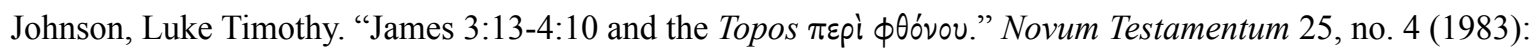
327-347.

Johnston, J. William. “James 4:5 and the Jealous Spirit.” Bibliotheca Sacra 170 (2013): 344-60.

Lappenga, Benjamin J. Paul's Language of Zñ̄os: Monosemy and the Rhetoric of Identity and Practice. Biblical Interpretation Series 137. Leiden: Brill, 2016.

Popkes, Wiard. "James and Scripture: An Exercise in Intertextuality." New Testament Studies 45 (1999): 213-29.

Saïd, Suzanne. "Envy and Emulation in Isocrates." Pages 217-34 in Envy, Spite, and Jealousy: The Rivalrous Emotions in Ancient Greece. Edinburgh Leventis Studies 2. Edited by David Konstan and N. Keith Rutter. Edinburgh: Edinburgh University Press, 2003. 